\title{
Clinical applications of the jugal lipectomy technique: case reports
}

\author{
Bárbara do Amaral Antunes ${ }^{1}$, Alan Robert Moreira Schmitt' ${ }^{2}$, Michel Abrão Neto ${ }^{3}$, Filipe Jaeguer ${ }^{4}$, Maria da \\ Graça Naclério-Homem ${ }^{5}$, Matheus Furtado de Carvalho ${ }^{6}$ \\ 'Dental School, Federal University of Juiz de Fora, Governador Valadares 35010-177, Brazil. \\ 2Department of Oral and Maxillofacial Surgery, University of the State of Rio de Janeiro, Rio de Janeiro 20551-030, Brazil. \\ ${ }^{3}$ Department of Oral and Maxillofacial Surgery, President Tancredo de Almeida Neves University, São Joao Del Rei 36301-182, Brazil. \\ ${ }^{4}$ Department of Oral and Maxillofacial Surgery, Pontifical Catholic University of Minas Gerais, Belo Horizonte 30535-901, Brazil. \\ ${ }^{5}$ Department of Oral and Maxillofacial Surgery, Federal University of São Paulo, São Paulo 05508-000, Brazil. \\ ${ }^{6}$ Department of Oral and Maxillofacial Surgery, Federal University of Juiz de Fora, Governador Valadares 35010-177, Brazil.
}

Correspondence to: Dr. Matheus Furtado de Carvalho, Department of Oral and Maxillofacial Surgery, Federal University of Juiz de Fora, Governador Valadares 35010-177, Brazil. E-mail: matcarodonto@yahoo.com.br

How to cite this article: Antunes BA, Schmitt ARM, Neto MA, Jaeguer F, Naclério-Homem MG, Carvalho MF. Clinical applications of the jugal lipectomy technique: case reports. Plast Aesthet Res 2018;5:11. http://dx.doi.org/10.20517/2347-9264.2018.03

Received: 22 Jan 2018 First Decision: 24 Feb 2018 Revised: 5 Mar 2018 Accepted: 5 Mar 2018 Published: 14 Mar 2018

Science Editor: Raúl González-García Copy Editor: Jun-Yao Li Production Editor: Huan-Liang Wu

\begin{abstract}
The adipose body of cheek is the tissue located in the buccal space. In the past, the partial removal of this tissue, called jugal lipectomy, was indicated to fill defects resulting from buccosinusal communications and/or maxillary resections. Recently, such technique became popular in facial aesthetics as it gives patients the feel of a more delicate face, in which the zygomatic bone appears to be more prominent due to the reduction in the volume of the cheeks. However, many professionals are unaware of how to establish the correct diagnosis of facial volume alterations, as well as in performing and treating the complications that may arise from jugal lipectomy. The aim of this paper is to present three clinical cases with different applications of jugal lipectomy, discussing some relevant aspects of surgical planning that involve the request for imaging exams and a previous study of this tissue's anatomical features.
\end{abstract}

Keywords: Face, lipectomy, adipose tissue, aesthetics

\section{INTRODUCTION}

Although previous studies on adipose body of cheek (ABC) have been brief and scarce in the literature, there is currently a greater interest by researchers in studying the anatomy of this support tissue, considered as an important factor influencing facial aesthetics ${ }^{[1]}$.

The ABC, also known as the "Bichat ball", was described in 1802 by French physiologist and anatomist

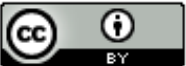

(C) The Author(s) 2018. Open Access This article is licensed under a Creative Commons Attribution 4.0 International License (https://creativecommons.org/licenses/by/4.0/), which permits unrestricted use sharing, adaptation, distribution and reproduction in any medium or format, for any purpose, even commercially, as long as you give appropriate credit to the original author(s) and the source, provide a link to the Creative Commons license, and indicate if changes were made. 


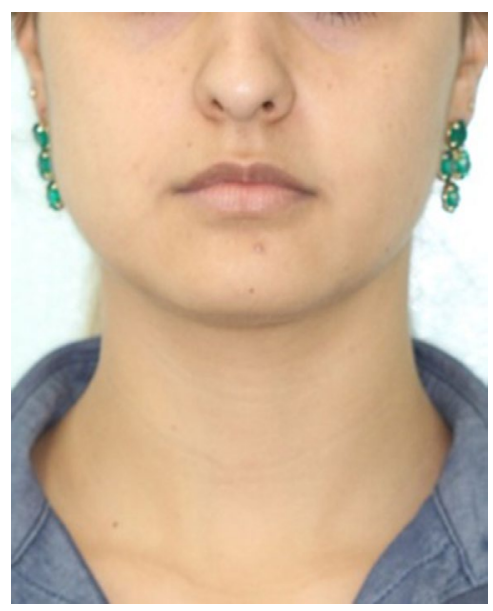

Figure 1. Front view

Marie François Xavier Bichat, father of modern histology. Histologically, the tissue is composed of the same type of fat present in other parts of the human body and is one of the last reserves to be consumed during weight loss ${ }^{[2]}$.

This adipose tissue is wrapped by a thin fibrous capsule that isolates it from other structures, divided into anterior, intermediate, and posterior lobes, fixed by six ligaments inserted in the maxilla, posterior region of zygoma, inner and outer rim of infraorbital fissure, temporal tendon, and buccal membrane. The anatomy of the $\mathrm{ABC}$ extension is complex and fills the space between the masticatory muscles (masseter, medial pterygoid, lateral pterygoid, and temporal). The posterior lobe presents four processes (buccal, pterygoid, pterygopalatine, and temporal), keeping a close relationship with blood vessels, branches of facial nerve, and the parotid duct The parotid duct and zygomatic and buccal branches of the facial nerve cross the anterior and lateral surfaces of the $\mathrm{ABC}$. The anterior surface of the $\mathrm{ABC}$ is covered by buccal branches of the facial nerve, while the lateral border is covered by zygomatic branches in almost all patients ${ }^{[3]}$.

Currently, the partial removal of this tissue is no longer restricted to functional indications for the correction of buccal defects, representing one of the most desired surgical procedures by patients in aesthetic clinics. However, many professionals are unaware of how to establish the correct diagnosis of facial volume alterations, as well as in performing and treating the complications that may arise from jugal lipectomy.

Clinical evaluation has been used as the sole method to indicate the surgical procedure. However, it is known that complementary exams such as computed tomography, magnetic resonance imaging, and ultrasonography can improve the diagnosis, avoiding unnecessary surgeries. They may be employed alone or in association, and there is no consensus about the best imaging modality. Thus, the aim of this paper is to present three cases with different clinical applications, highlighting the importance of anatomical and imaging knowledge for better planning and execution of the surgical technique.

\section{CASE REPORT}

\section{Case 1}

A female patient, 24 years old, sought the service of maxillofacial surgery complaining of a chronic bite of the bilateral jugal mucosa and aesthetic dissatisfaction with excessive cheek volume. She reported good health status and absence of systemic alterations. A facial examination revealed a rounded face [Figure 1] associated with the suspicion of masseter hypertrophy, which was discarded after palpation of the 

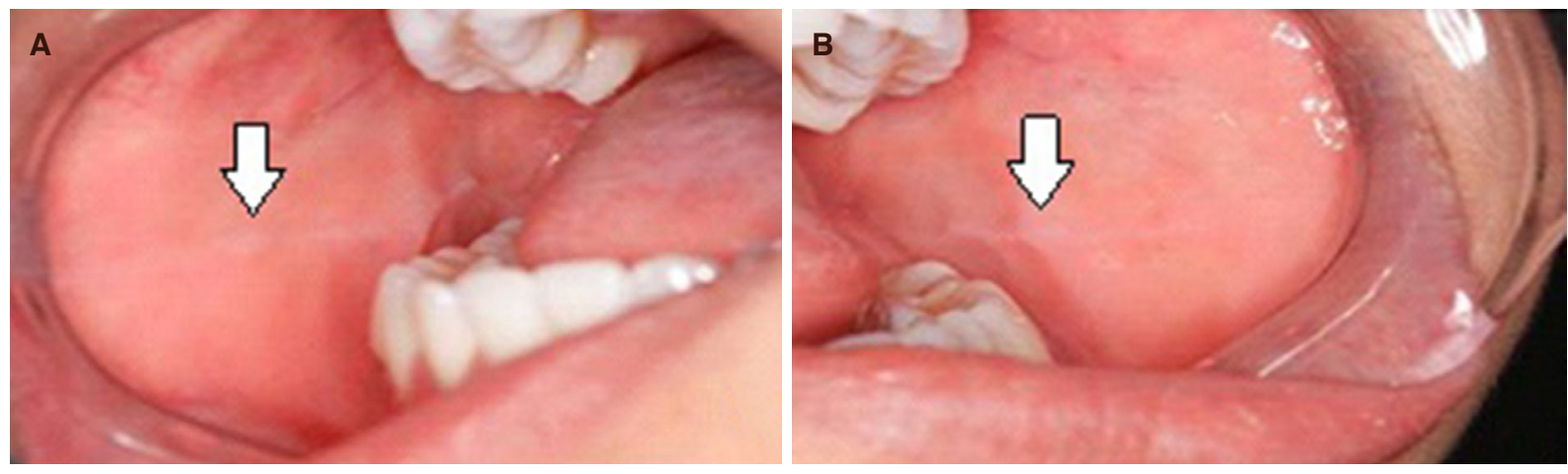

Figure 2. Intraoral photographs on the right $(A)$ and left $(B)$ sides showing keratinization lines
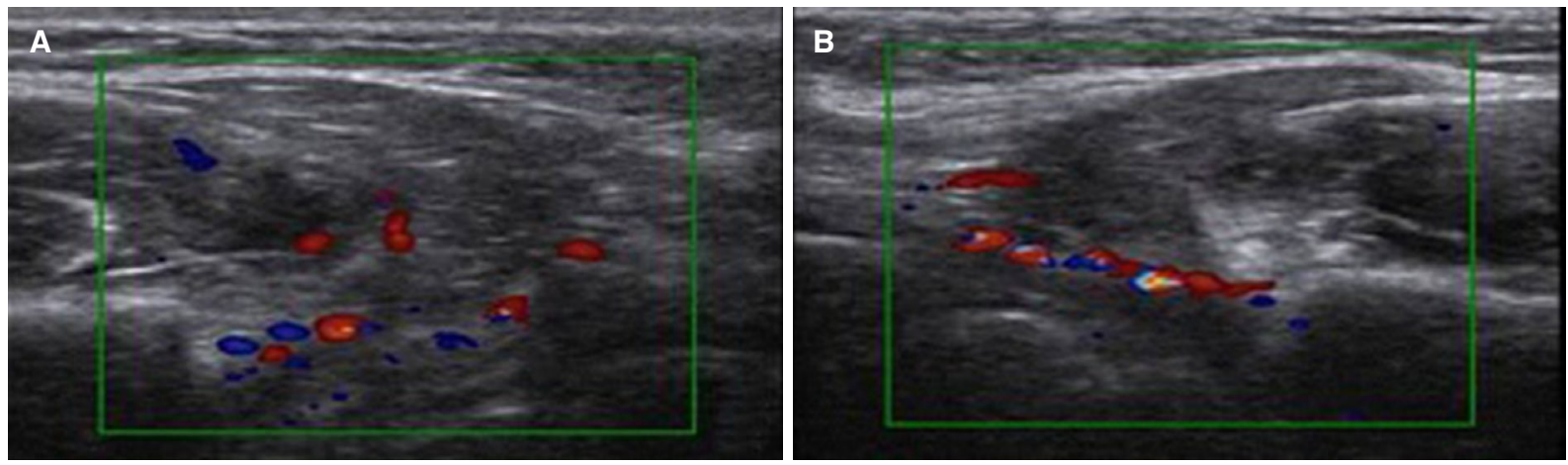

Figure 3. Doppler ultrasonography on the right (A) and left (B) sides, showing blood vessels over the surgical area

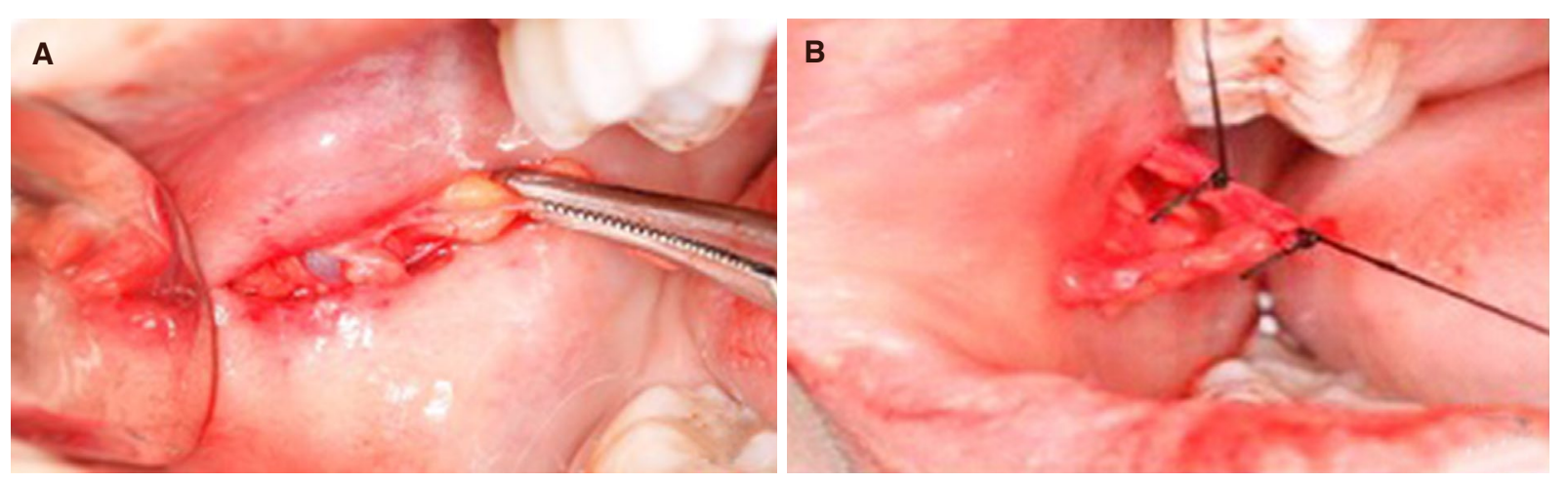

Figure 4. Intrabuccal photographs from the right side showing the adipose body of cheek identification (A) and link of blood vessels (B)

musculature and request for imaging exams. An intrabuccal examination revealed the presence of a white line of keratinization, asymptomatic, parallel to the occlusion line, suggestive of an alba line [Figure 2]. Doppler ultrasound revealed symmetry of the $\mathrm{ABC}$ on the right and left sides and a very close relationship of the branches of arteries and buccal veins on both sides [Figure 3].

Jugal lipectomy was performed under local anesthesia, using 2\% lidocaine and 1:100,000 epinephrine, and a parallel incision was made immediately adjacent to the mucosal bite line. The access distance was at least $1 \mathrm{~cm}$ below the parotid caruncle and could have been extended up to $2 \mathrm{~cm}$. It is recommended to start the incision $1 \mathrm{~cm}$ behind the caruncle, avoiding trauma in the masseter muscle. After submucous divulsion, a portion of the $\mathrm{ABC}$ was identified along with blood vessels, which were linked with 4-0 silk thread [Figure 4]. Next, part of the buccal extension of the $\mathrm{ABC}$ was pulled by rotating movements by a Halstead forceps to remove the tissue and the mucosa was sutured with 3-0 silk thread. To prevent edema, $8 \mathrm{mg}$ of 

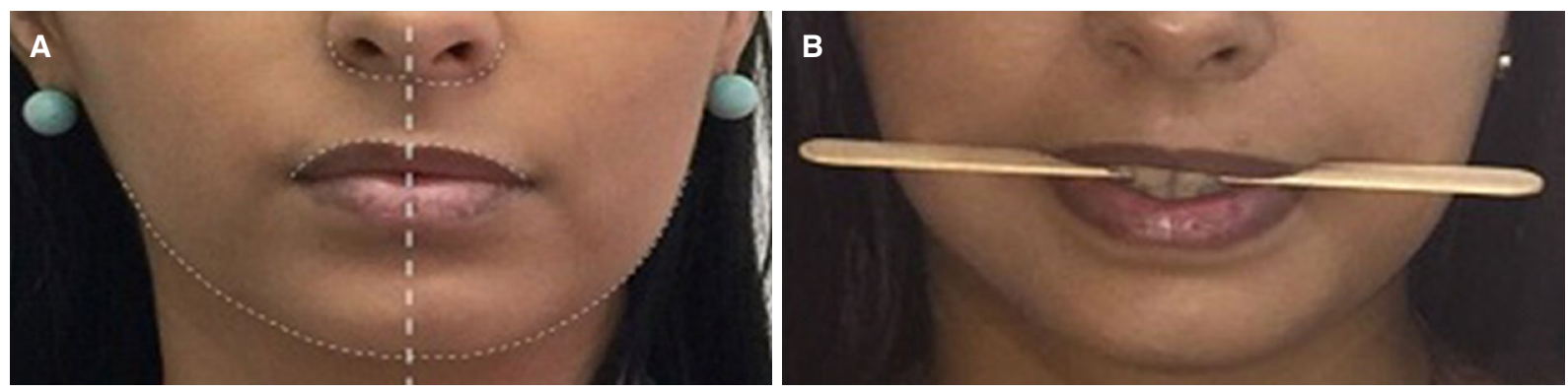

Figure 5. Preoperative front view showing facial asymmetry $(A)$ and occlusal unevenness (B)

dexamethasone was prescribed $1 \mathrm{~h}$ before surgery. After surgery, $750 \mathrm{mg}$ of paracetamol every $6 \mathrm{~h}$ and $100 \mathrm{mg}$ of nimesulide every $12 \mathrm{~h}$ were prescribed for three days for pain control.

Patient is in the second postoperative year with no complaint of biting jugal mucosa.

\section{Case 2}

A female patient, 29 years old, sought the service of maxillofacial surgery complaining of facial asymmetry and reporting good health status and absence of systemic alterations. Facial examination revealed a slight increase in volume in the cheek region on the left side. Intraoral examination showed an unevenness of the occlusal plane and class I occlusion [Figure 5]. Magnetic resonance imaging did not identify alterations in bone tissue, such as condylar hyperplasia, and/or changes in soft tissue, such as masseter hypertrophy and/ or temporomandibular joint disorders [Figure 6]. The surgical technique was the same used in the first reported case, removing $2.8 \mathrm{~mL}$ of fat from the buccal extension of the left $\mathrm{ABC}$. In addition to the preand postoperative medications, a compressive dressing was performed to better control edema. After four months of follow-up, the patient is satisfied with the facial contour and better symmetry in the region of upper lip and the wing of the nose [Figure 7].

\section{Case 3}

A male patient, 22 years old, sought the service of maxillofacial surgery complaining of passage of liquid from the oral cavity to the nasal cavity during feeding. In the anamnesis, he reported good health, absence of systemic alterations, and a history of tooth extraction 3 months ago. Facial examination showed palpation sensitivity in the region of the right maxillary sinus associated with a buccosinusal fistula with active drainage of purulent secretion [Figure 8]. Waters view radiography identified a suggestive image of generalized thickening of maxillary sinus mucosa, which was confirmed by nasal endoscopy and lead to the diagnosis of maxillary sinusitis on the right side [Figure 9].

After remission of chronic sinusitis and treatment with hydration, systemic antibiotic therapy, and nasal decongestant, the surgery was scheduled to close the fistula [Figure 10]. Given that it required a small amount of adipose tissue, a $1-\mathrm{cm}$ gingivobuccal incision was performed, located $1 \mathrm{~cm}$ above the parotid caruncle. After divulsion, a non-pedicled portion of the $\mathrm{ABC}$ was removed, transferred, and sutured over prior fistulectomy surgery. The sliding palatal flap was then positioned and sutured onto the ABC. After four months of follow-up, a healthy mucosa was observed and there were no signs suggesting maxillary sinusitis.

\section{DISCUSSION}

The anatomy of $\mathrm{ABC}$ has been investigated by several authors, and few studies have made a careful analysis of tissue dimensions and volumes with the aid of imaging exams ${ }^{[4-6]}$. Loukas et al. ${ }^{[7]}(2006)$ measured the $\mathrm{ABC}$ of 20 cadavers through computed tomography (CT) and magnetic resonance imaging 


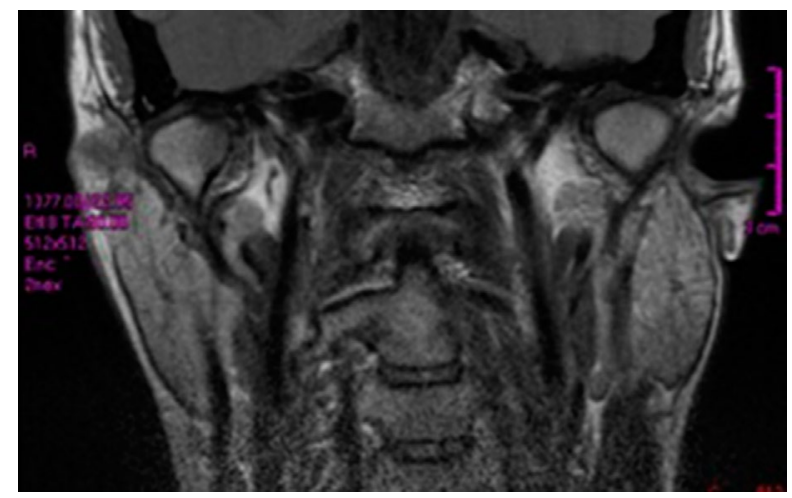

Figure 6. Magnetic resonance imaging identifying normal mandibular condyle and chewing muscles

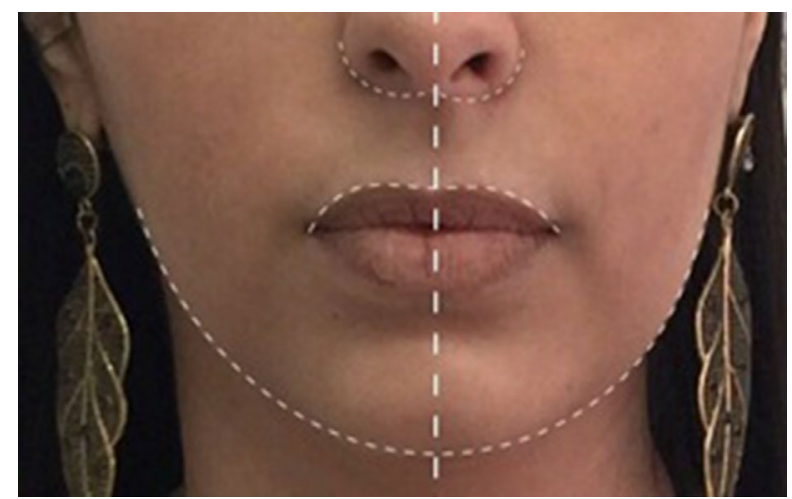

Figure 7. Postoperative front view showing correction in the facial contour

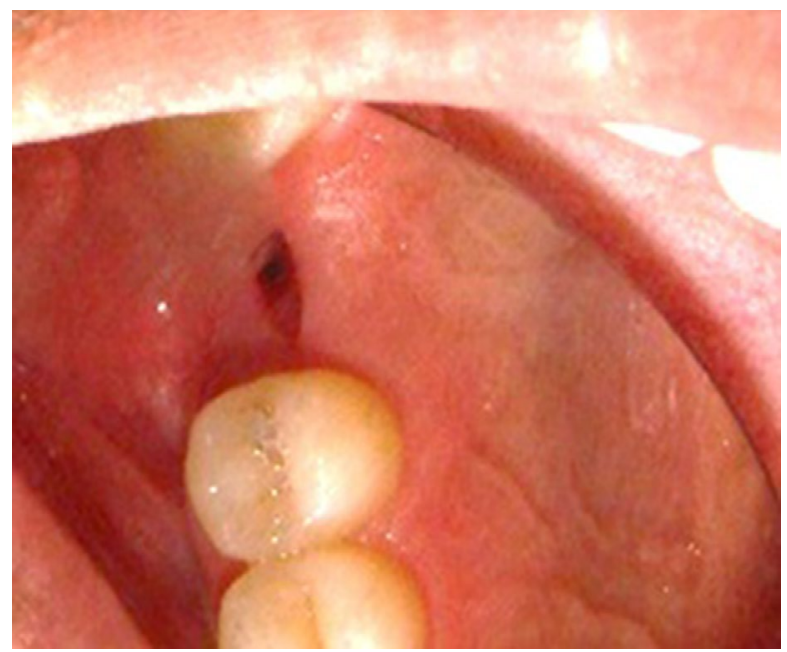

Figure 8. Intraoral photographs showing the buccosinusal fistula

(MRI), concluding that the mean volume in men was 10.2 and $8.9 \mathrm{~mL}$ in women, weighing approximately 9.7 g. No significant differences between genders was observed.

As reported in the first case, a third imaging examination may be required for the study of $\mathrm{ABC}$ anatomy: ultrasonography (USG). This exam is based on the transmission of sound waves and reflection of these waves when they reach an interface between tissues of different densities. It is an easy-to-perform, non- 


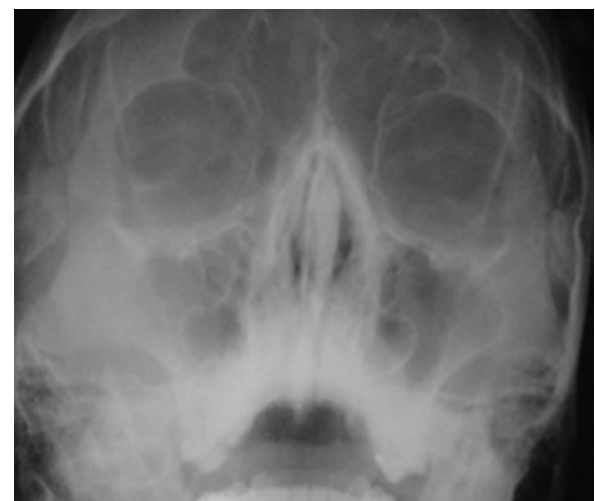

Figure 9. Waters view radiography showing opacification of the right maxillary sinus
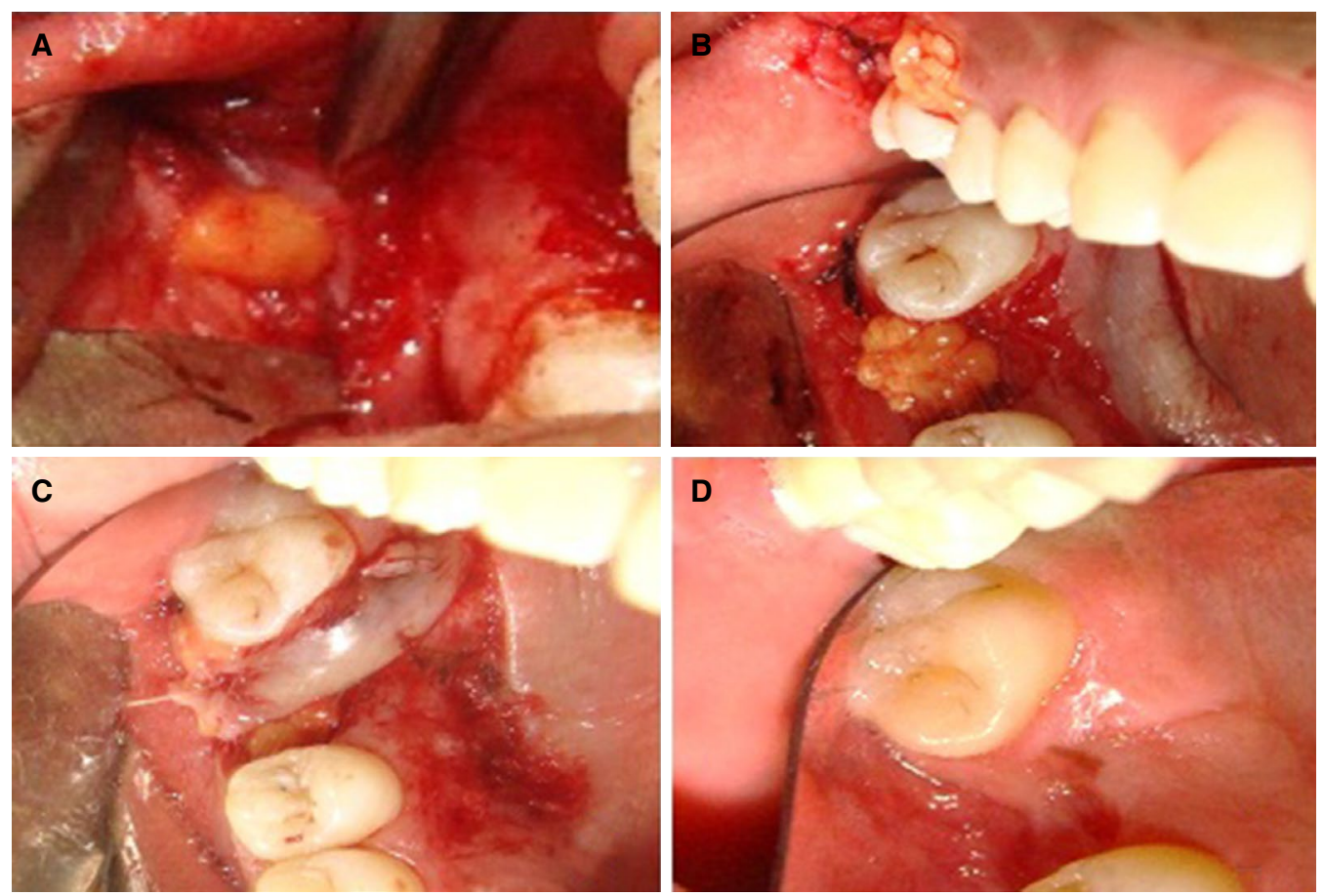

Figure 10. (A) Gingivobuccal access and adipose body of cheek ( $A B C$ ) identification; (B) bransposition of part of $A B C$ for the region of buccosinusal fistula; (C) rotation and suturing of palatal flap for tissue nutrition; (D) clinical aspect after four months of follow-up

invasive exam with no image superimposition, does not use ionizing radiation, and has a relatively low cost compared to CT and MRI ${ }^{[8]}$. Because it is less widespread in maxillofacial surgery, there is a shortage of qualified professionals to perform the exam and interpret the images.

In attempt to improve such imaging findings, Jaeger et al. ${ }^{[9]}$ (2016) presented a protocol for predicting the anatomy of buccal extension of ABC using USG. It was possible to identify tissues of small, or even the absence of, buccal extension, contraindicating jugal lipectomy and avoiding unnecessary surgeries. In the first reported case, we used the USG exam similarly to these authors, finding a symmetry of buccal extensions of $\mathrm{ABC}$ on both sides, with a volume of $2.4 \mathrm{~mL}$ on the right side and $2.2 \mathrm{~mL}$ on the left side. In the second case, the $\mathrm{ABC}$ volume calculated from MRI showed a difference of $1.5 \mathrm{~mL}$. In this context, it is important to highlight the importance of preoperative imaging exams to study the symmetries or asymmetries of this tissue for surgical planning. 
Each imaging exam has a contribution to make in the study of the anatomy of the $\mathrm{ABC}$, and should be requested after the clinical exam according to the diagnostic hypothesis. CT is more accurate for hard tissues analysis, while USG and MRI provide more detail for soft tissues. Due to a greater detailing provided by images, CT and MRI can be useful for the study of face volumetric alterations that occur with aging $^{[5]}$ and the identification of pathologies in the hard or soft tissues of the maxillofacial region, such as masseter hypertrophy and condylar hyperplasias, as was suspected in the first and second reported cases, respectively.

Jugal lipectomy also presents applications other than those described in the three clinical cases ${ }^{[10]}$. Bansal et al. ${ }^{[1]}$ (2015) evaluated the viability of $A B C$ as interposition material after arthroplasty and concluded that the volume of $1.1 \mathrm{~mL}$ of fat is efficient and stable as a barrier for preventing temporomandibular ankylosis. Recently, the literature discusses the ability of $\mathrm{ABC}$ to be an important source of mesenchymal stem cells, promising to produce bone tissue, muscle, cartilage, and fat. However, such information is not yet accurate and further studies are needed ${ }^{[12,13]}$.

Correction of oral defects, including closure of buccosinusal fistulae with ABC pedicled graft, is the most common indication found in the literature for jugal lipectomy ${ }^{[14]}$. The success of this grafting can be attributed to the rich vascularization of adipose tissue, an important condition for the long healing period $^{[15]}$. However, even when a non-pedicled graft was used, as reported in the third clinical case, there was excellent tissue stability, and local vascularization was also provided by the palatal flap. Satisfactory results were also found in free grafts for treatment of patients with cleft lip and palate in the anterior region of maxilla ${ }^{[16]}$.

Three surgical accesses for jugal lipectomy are described in the literature: (1) $1 \mathrm{~cm}$ below the opening of parotid duct (Matarasso method), (2) behind the parotid papilla (Stuzin method), and (3) incision superior to the gingivobuccal sulcus ${ }^{[17]}$. In the first and second reported cases, the Matarasso method was used to provide wide and direct access to the buccal space, allowing the removal of a larger volume of $\mathrm{ABC}$ and its buccal extension, directly related to the contour of the cheek. In the third clinical case, jugal lipectomy did not present an aesthetic indication. Therefore, the gingivobuccal access was chosen since the aesthetic repercussion is almost insignificant. Upon performing an intraoral approach carefully to not pull the $\mathrm{ABC}$ and resecting only that which easily protrudes with gentle pressure, complications of excision for lipodystrophy or a pseudo herniated buccal fat pad are rare. The most likely complication would be over resection.

Although complications are infrequent ${ }^{[18]}$, lesions in the parotid gland, vascular plexus (branches of facial artery, maxillary artery, and transverse artery of the face), and the buccal branch of facial nerve may occur $^{[19]}$. While the parotid duct presents a more lateral path in relation to the $\mathrm{ABC}$, the vessels and buccal branches have a more superficial path and can go through the ABC extension ${ }^{[20]}$. Lesions of these structures can cause dry mouth sensation, the formation of large bruises, and even facial paralysis. Treatments include surgical repair of the duct, drainage of bruises and linking of blood vessels, anastomosis or grafting of neural tissue, and may be associated with laser therapy and corticosteroids. There were no hospitalizations, accidents, or complications in the three cases presented, and the procedure was performed at the dental office under local anesthesia. Superselective microcatheter angiography and embolization has been shown to be an effective modality for prompt treatment of bleeding from traumatic facial injury and refractory epistaxis when local methods fail to achieve hemostasis ${ }^{[21]}$. Trismus, infection, asymmetries, or cheek depressions may also occur, resulting from inadequate and lopsided removal of adipose tissue.

Despite these complications, it is important to highlight that jugal lipectomy is a simple technique with few variations, fast execution, and low morbidity. It is essential to know the $\mathrm{ABC}$ anatomy of each patient through clinical examination and complementary imaging exams. 


\section{DECLARATIONS}

\section{Authors' contributions}

Literature search, manuscript preparation, manuscript editing: Antunes BA

Clinical studies, manuscript preparation: Schmitt ARM, Neto MA, Jaeguer F

Design, definition of intellectual content, and manuscript review: Naclério-Homem MG

Concept, definition of intellectual content, literature search, clinical studies, manuscript editing, and manuscript review: Carvalho MF

\section{Financial support and sponsorship}

None.

\section{Conflicts of interest}

There are no conflicts of interest.

\section{Patient consent}

The proper consent of the patients was taken for carrying out all the treatment.

\section{Ethics approval}

The procedures followed were in accordance with ethical standards of the responsible committee on human experimentation by Federal University of Juiz de Fora (CAAE 74413617.6.0000.5147).

\section{Copyright}

(c) The Author(s) 2018.

\section{REFERENCES}

1. Marlière DAA, Lovisi CB, Schmitt ARM, Sotto-Maior BS, Chaves Netto HDM. Orthognathic surgery combined with partial lipectomy of the buccal fat pad: case report on optimization of esthetic outcome. J Pharm Pharmacol 2017;5:565-71.

2. Bichat MFX. Anatomie générale appliqué a la physiologie et a la médecine. 1st ed. Paris: Grosson, Gabon; 1801. p.35-6. (in French)

3. Kahn JL, Sick H, Laude M, Koritké JG. The buccal adipose body (Bichat's fat-pad). Morphological study. Acta Anat (Basel) 1988;132:417. (in French)

4. Gierloff M, Stöhring C, Buder T, Gassling V, Açil Y, Wiltfang J. Aging changes of the midfacial fat compartments: a computed tomographic study. Plast Reconstr Surg 2012;129:263-73.

5. Guryanov RA, Guryanov AS. Ct anatomy of buccal fat pad and its role in volumetric alterations of face. Int Arch Photogramm Remote Sens Spatial Inf Sci 2015;5:33-6.

6. Xiao H, Bayramiçlii M, Jackson IT. Volumetric analysis of the buccal fat pad. Eur J Plast Surg 1999;22:177-80.

7. Loukas M, Kapos T, Louis RG Jr, Wartman C, Jones A, Hallner B. Gross anatomical, CT and MRI analyses of the buccal fat pad with special emphasis on volumetric variations. Surg Radiol Anat 2006;28:254-60.

8. Marotti J, Heger S, Tinschert J, Tortamano P, Chuembou F, Radermacher K, Wolfart S. Recent advances of ultrasound imaging in dentistry--a review of the literature. Oral Surg Oral Med Oral Pathol Oral Radiol 2013;115:819-32.

9. Jaeger F, Castro CHBC, Pinheiro GM, Souza ACRA, Junior GTM, Mesquita RA, Menezes GB, Souza LN. A novel preoperative ultrasonography protocol for prediction of bichectomy procedure. Arquivo Brasileiro de Odontologia 2016;12:7-12.

10. Yousuf S, Tubbs RS, Wartmann CT, Kapos T, Cohen-Gadol AA, Loukas M. A review of the gross anatomy, functions, pathology, and clinical uses of the buccal fat pad. Surg Radiol Anat 2010;32:427-36.

11. Bansal V, Bansal A, Mowar A, Gupta S. Ultrasonography for the volumetric analysis of the buccal fat pad as an interposition material for the anagement of ankylosis of the temporomandibular joint in adolescent's patients. Br J Oral Maxillofac Surg 2015;53:820-5.

12. Abuna RP, De Oliveira FS, Santos Tde S, Guerra TR, Rosa AL, Beloti MM. Participation of TNF-a in inhibitory effects of adipocyteson osteoblast differentiation. J Cell Physiol 2015;231:204-14.

13. Broccaioli E, Niada S, Rasperini G, Ferreira LM, Arrigoni E, Yenagi V, Brini AT. Mesenchymal stem cells from Bichat's fat pad: in vitro comparison with adipose-derived stem cells from subcutaneous tissue. Biores Open Access 2013;2:107-17.

14. Kim MK, Han W, Kim SG. The use of the buccal fat pad flap for oral reconstruction. Maxillofac Plast Reconstr Surg 2017;39:5. 
15. Tideman H, Bosanquet A, Scott J. Use of the buccal fat pad as a pedicled graft. J Oral Maxillofac Surg 1986;44:435-40.

16. De Castro CH, de Souza LN, Fernandes Santos Melo M. Use of the buccal fat pad as free graft for closure of oronasal fistula in a cleft palate patient. J Craniofac Surg 2015;26:14-6.

17. Meyer E, Liebenberg SJ, Fagan JJ. Buccal fat pad - a simple, underutilised flap. S Afr J Surg 2012;50:47-9.

18. Thomas MK, D'Silva JA, Borole AJ. Facial sculpting: comprehensive approach for aesthetic correction of round face. Indian J Plast Surg 2012;45:122-7.

19. Wen H, Ma L, Sui Y, Jian X. The application of facial liposuction and fat grafting in the remodeling of facial contour. Zhonghua Zheng Xing Wai Ke Za Zhi 2015;3:89-92.

20. Hwang K, Cho HJ, Battuvshin D, Chung IH, Hwang SH. Interrelated buccal fat pad with facial buccal branches and parotid duct. $J$ Craniofac Surg 2005; 16:658-60.

21. Engdahl R, Nassiri N, Mina B, Drury J, Rosen R. Superselective microcatheter embolization of hemorrhage after buccal lipectomy. Aesthetic Plast Surg 2012;36:742-5. 